\title{
The Proportion of Non-operating Income, and Analysts' Forecasts
}

\author{
Andrew Ayimbila Anabila \\ Correspondence: Andrew Ayimbila Anabila, Room 220C College of Business Administration, 1201 West \\ University Drive, University of Texas - Pan American, Edinburg, Texas 78539, USA. Tel: 1-956-665-8084. \\ E-mail: anabilaaa@utpa.edu
}

Received: May 4, 2012

Accepted: August 20, 2012

Online Published: September 4, 2012

doi:10.5539/ijef.v4n10p15

URL: http://dx.doi.org/10.5539/ijef.v4n10p15

\begin{abstract}
The US Senate Committee that investigated the Enron disaster assessed the role of analysts. At issue was whether analysts misled the public by ignoring warning signals that included a high proportion of non-operating income. Non-operating income derives from secondary activities like investments, but operating income is from the primary business activities like manufacturing. While the analysts admitted their limited ability to forecast Enron's earnings, they denied any intentional deceit and claimed that they were misled by Enron. This study asks whether analysts' ability to predict earnings is generally negatively associated with the proportion of non-operating income. The rationale is to determine whether the limited ability of analysts to predict earnings for Enron was an isolated incident or a pervasive one that applies to other firms. If pervasive, then another such disaster could occur without a warning from analysts. First, I examine the incentives for firms to resort more to non-operating income rather than focus on Operating income. Then I examine the association between analysts' forecast attributes and the ratio of nonoperating to operating income. The results show that non-operating income and operating income are negatively associated, suggesting that firms use non-operating income to manage their operating results. Also, analysts' forecast inaccuracy and dispersion are positively associated with the ratio of non-operating income to operating income. These results imply that analysts are generally inefficient in predicting earnings of firms with a high proportion of non-operating income.
\end{abstract}

Keywords: operating, non-operating, income, analysts, forecasts, accuracy, dispersion, bias

\section{JEL Classification: M40}

\section{Introduction}

To forestall future corporate scandals like Enron's collapse, the Senate committee that investigated the Enron failure assessed the roles of various parties, including financial analysts. During the committee hearings, its members charged that analysts intentionally failed to warn the public of poor future earnings for Enron, and even misled them into expecting the opposite. The committee, supported by experts, argued that the analysts had ignored vital signals such as an increasing proportion of non-operating income. (Note 1) The analysts admitted inefficiency, but denied intentionally misleading the public.

Like Enron, firms have the discretion to focus on their primary operations (like manufacturing) or add non-operating activities (like investments in securities, etc). (Note 2) Fairfield, Sweeney, \& Yohn, (1996), use time-series analysis to show that non-operating (compared to operating) income is less related to future bottom-line earnings. Thus the two classes of income have different implications for future earnings. However, the implication of each class of income for analysts' forecasts has not been examined.

In this study, I ask if analysts' forecast attributes are negatively associated with the proportion of non-operating income. By forecast attributes, I am referring to the forecast accuracy and precision (opposite of dispersion, which is a proxy for information asymmetry). The objective is to ascertain whether the analysts' inability to predict Enron's earnings, because of the firm's high proportion of non-operating income, was an isolated rather than a widespread phenomenon. That is, are managers generally using non-operating income to mask their systematic poor operating performance from the analysts and the public? The latter reason would suggest that another disaster similar to Enron's could occur, without the slightest hint from analysts. To avert this, it is necessary to improve disclosure quality and increase pressure on analysts so that they will conduct adequate research and be more responsible for their research outputs. 
To address the research question, I compute the proportion of non-operating income relative to (divided by) operating income. For the purpose of this exposition, I refer to this ratio as "Discretion" ratio hereafter. (Note 3) This ratio is also computed and used in Bowen (1981) to examine properties of non-operating income in the electric utility industry. (Note 4) I then examine the association between the ratio and analysts' forecast attributes. I Use firm years at the intersection of Compustat annual active and research files and FirstCall earnings estimates and actual files, from 1990 through 2004 fiscal years. In my tests for the association between the Discretion ratio, analysts' forecast errors and dispersion, I first use simple statistical tests. I then support these tests with multivariate regressions that control for the following determinants of forecast error and dispersion identified by prior research: size (Brown, Richardson \& Schwagger, 1987), analyst following (Lys \& Soo 1995), performance or profitability (Brown, 2001), business segment diversification (Thomas, 2002) and international or geographic segment diversification (Duru \& Reeb, 2002).

I find a negative association between non-operating and operating income. This suggests that firms use non-operating income to smooth their operating income. The results of my main analyses are as follows: First, forecast optimism bias and inaccuracy are positively associated with the discretion ratio. Second, forecast dispersion is positively associated with the discretion ratio. The findings are consistent with my expectations, and are robust to the forecast horizon (one, two, etc periods ahead).

The foregoing results suggest that management's use non-operating income to smooth earnings, and this tends to mislead analysts. This is because first non-operating income has a weaker relation than operating income, to the operating expertise of the investing management, since the latter does not operate its nonoperating assets. (Note 5) Second, non-operating income increases the complexity of the earnings prediction activity since they add to the classes of income that analysts should research into. Therefore, analysts forecasting ability is negatively associated with the proportion of non-operating income.

These findings explain why, like Enron, firms that are performing poorly in their primary operations, engage in non-operating activities such as investments for which they can avoid consolidation. The results show that analysts provide overly optimistic (overstated) forecasts for such firms, which leads to their overvaluation as happened for Enron, since prices are driven by analysts' forecasts (Liu, Nissim \& Thomas, 2002). Further, the high forecast dispersion associated with such firms is associated with overvaluation. This is because higher divergence of opinion is positively associated with overpricing (see Diether, Malloy \& Scherbina, 2002; Miller, 1977, 2001).

This study draws attention to a source of analysts' inefficiency. It shows that analysts have significant cognitive limitations for firms with a high proportion of non-operating income. Therefore, such firms need more scrutiny by analysts, otherwise like Enron, firms that wish to elude analysts could resort more to non-operating activities to increase the proportion of their non-operating income. Also, accounting rules that seek to ensure that de facto control or risk exposure is reported would help arouse increased attention and scrutiny of analysts to what would otherwise be reported as non-operating income for these firms. In this regard, FIN 46 (R.) which requires consolidation on the basis of majority exposure to benefits and risks is a welcome pronouncement that should be strongly enforced.

The remainder of the study proceeds as follows. Section 2 links this study to prior research. Section 3 describes the methods, data and sample used in this study. Section 4 presents the detailed results and sensitivity tests, and section 5 presents the summary and conclusion of the study.

\section{Relation to Prior Literature}

Analysts' forecasts are used for valuation and as a proxy for investors' expectations. The determinants of forecast accuracy and dispersion are of interest to academics and practitioners alike. For example, if the determinants of the forecast accuracy are related to financial reporting or disclosure, the accounting profession could consider reducing forecast errors and dispersion by prescribing appropriate financial reporting standards. Also, identifying the determinants of forecast accuracy would guide academics to determine appropriate control variables when examining the relation between forecast attributes and other variables of interest (Duru \& Reeb, 2002).

Brown et al. (1987) show that the superiority of analysts' forecasts relative to time series forecasts increases in firm size (a proxy for the dimensionality of the disclosure information set and complexity), and inherent uncertainty (dispersion of analysts' forecasts) of the firm. Wiedman (1996) show that because of these attributes identified in Brown et al. (1987), analysts' forecasts constitute a better proxy for investor's expectations than time series forecasts. Duru \& Reeb (2002) show that international diversification is positively associated with mean optimism bias and inaccuracy of analysts' forecasts. They argue that international diversification increases 
the complexity of forecasting since analysts may not possess the expertise for the foreign environments in which the diversified firm operates.

The following describe the contribution of this study to the literature. First, studies have shown the importance of analysts' forecast dispersion for firm value. Gebhardt, Lee \& Swaminathan (2001) shows that forecast dispersion is associated with lower returns premium. Similarly, Diether et al. (2002), show that future returns are negatively associated with dispersion. Miller $(1977,2001)$ show that divergence in opinion is associated with overpricing, since prices clear beginning with the highest bidder, downwards. (Note 6) The foregoing studies generally describe dispersion as being a result of differing opinions among analysts, without specifying the fundamental operating circumstances underlying variations in forecast inaccuracy and dispersion across firms. This study relates the dispersion to the mix of non-operating and operating income.

Duru \& Reeb (2002) suggest that international diversification is associated with inaccuracy of forecasts for future earnings, but do not examine divergence of opinion among analysts, and its fundamental determinants. Thomas (2002) links forecast dispersion to lines of business diversification but ultimately concludes that this link is at best a weak one. Studies that examine diversification focus on attributes of the operating income. This study focuses on two different classes of income from continuing operations: the mix of non-operating relative to operating income.

Second, Fairfield et al. (1996) show that for a time series model, the position of an item in the income statement determines its ability to help predict the bottom line earnings of the firm. Specifically, the study shows that operating, non-operating income and special items are useful for predicting bottom line income in decreasing order. This study does not examine special items because they are one-off in nature and tend not to be the focus of analysts (Philbrick \& Ricks, 1991). Operating income and non-operating income are both of a continuing nature and so it would seem puzzling that they differ in their predictive ability for income from continuing operations. As per the introduction this study identifies attributes of non-operating income that explain why it is associated with analysts' forecast attributes.

Fourth, it has been quite puzzling to many that the recent financial scandals such as involving Enron Corporation came to pass without any advance warning by financial analysts who are supposed to predict the future earnings. Admittedly, the financial reporting was replete with falsehood, but were there signals that should have aroused analysts' curiosity? This study shows that analysts' inefficiency generally increases in the proportion of non-operating income relative to operating income.

\section{Methodology, Data and Sample}

I examine the relation between the Discretion ratio, and the following attributes of analysts' forecasts: forecast bias, inaccuracy, and dispersion. For each firm year, I define forecast bias $\left(F B I A S_{j}\right)$ and forecast inaccuracy $\left(F A C C U_{j}\right)$ as follows:

$$
F B I A S_{j}=\left(F A C T_{j}-F E P S_{j}\right) / a b s\left(F A C T_{j}\right) ; \quad F A C C U_{j}=\text { Absolute }\left\{F B I A S_{j}\right\}
$$

I also define forecast dispersion $\left(F D I S P_{j}\right)$ as;

$$
F D I S P_{j}=\left\{\text { Stdev }_{j} / \text { absolute }\left(F E P S_{j}\right)\right\}
$$

The variable $F A C T_{j}$ represents the FirstCall reported actual EPS for the year, $F E P S_{j}$ represents the mean earnings forecast ('Meanest' in FirstCall) as of $\mathrm{j}$ months from the earnings announcement. Next, I define Discretion ratio (DISCRET) as:

$$
\text { DISCRET }=\text { (Non-operating Income / Operating Income) }
$$

Non-operating income is Compustat annual data61. Operating income is Compustat annual data178. Size (SIZM) is the $\log$ of total market value in millions of dollars (absolute value of Compustat annual data199 $\mathrm{x}$ data25). Business segment concentration (BADEX) is the sum of the squares of the assets of business segments divided by the square of the total of the assets for the firm year; and geographic (also known as international or global) segment concentration (GADEX) equals the sum of the squares of the assets of the geographic segments divided by the square of the total assets for the firm year. (Note 7) For analyst following $\left(\mathrm{ANAFO}_{\mathrm{j}}\right)$, I use the number of estimates reported in FirstCall. I proxy for overall firm level profit using the FirstCall reported actual EPS scaled by lagged market value. (Note 8) I report the definition and computation of all the variables in Appendix 1.

I compute summary statistics and correlations coefficients. I also use multivariate analyses in which I control for the determinants of forecast attributes identified in prior research. I estimate cross-sectional regressions using the following models:

$$
{ }^{\prime} \text { FORP }_{, i}=\beta_{0}+\beta_{1} \text { DISCRET }_{i}+\beta_{2} \text { ROEIM }_{i}+\beta_{3} \text { SIZM }_{j, i}+\beta_{4} \text { BADEX }_{i}+\beta_{5} \text { GADEX }_{i}+\beta_{6} A N A F O_{i}+\varepsilon_{i}
$$




$$
D^{\prime} \text { FORP }_{, i}{ }_{i}=\beta_{0}+\beta_{1} D D I S C R E T_{i}+\beta_{2} \text { DROEIM }_{i}+\beta_{3} D S I Z M_{j, i}+\beta_{4} D B A D E X_{i}+\beta_{5} D G A D E X_{i}+\beta_{6} D A N A F+\varepsilon_{i}
$$

Where 'FORP' ${ }_{i}$ equals the values FBIAS ${ }_{i}$, FACCU $_{\mathrm{i}}$ and FDISP $_{\mathrm{i}}$ respectively in each set of analysis. Model (4) examines the levels and model (5) examines the first difference of all these variables.

I estimate the regressions for each year, and then summarize the results for all the years. This is because the sample covers many (15) years and it is the fashion in recent academic literature to use the annual regressions when many years are studied, so as to control for serial correlation of the independent variables. I also confirm that instead of estimating annual regressions and then summarizing the parameters, estimating the regressions for the pooled sample yields results that point to the same conclusion.

The sample comprises of US firm year observations at the intersection of Compustat annual active and research files, and FirstCall detailed estimates file (which I summarize for the mean, standard deviation and number of forecasts), for the 15 years from 1990 through 2004. I include firms of all industry categories (industrial/commercial, financial services and utilities) so that the results may be as generalized as possible.

For inclusion in my sample, firms must have positive values for shareholders' equity, total assets and operating income. (Note 9) Firms must also have dispersion of analysts' forecast, in the month preceding the earnings announcement. A total of 50,003 firm years from Compustat have the relevant financial variables, but of these only 25,976 meet the requirements for forecast data outlined above. (Note 10) I winsorize the discretion ratio, forecast bias, inaccuracy and dispersion, at the top and bottom 1 percent. Without winsorizing, I find that the regression parameters are directionally similar but less precise due to extreme values. The analysts' forecast attributes are based on the analysts' forecasts as of the month before earnings announcement. Following Thomas (2002), I choose this horizon for the analysts' forecasts to minimize the generally high analysts' optimism bias in forecasts at earlier horizons. I present summary statistics of the variables in Table 1.

Table 1. Descriptive statistics

\begin{tabular}{|c|c|c|c|c|c|c|}
\hline Variable & Definition & Mean & Stdev & P25th & P50th & P75th \\
\hline $\mathrm{ANAFO}_{\mathrm{t}}$ & Analyst following & 6.984 & 5.317 & 3.000 & 5.000 & 9.000 \\
\hline FBIAS $_{t}$ & Forecast error & -0.026 & 0.259 & -0.012 & 0.006 & 0.031 \\
\hline $\mathrm{FACCU}_{\mathrm{t}}$ & Forecast (in)accuracy & 0.106 & 0.289 & 0.008 & 0.024 & 0.067 \\
\hline FDISP $_{t}$ & Forecast dispersion & 0.066 & 0.179 & 0.008 & 0.017 & 0.042 \\
\hline DFBIAS $_{\mathrm{t}}$ & FBIAS $_{\mathrm{t}}-$ FBIAS $_{\mathrm{t}-1}$ & -0.006 & 0.381 & -0.038 & -0.002 & 0.030 \\
\hline DFACCU $_{\mathrm{t}}$ & $\mathrm{FACCU}_{\mathrm{t}}-\mathrm{FACCU}_{\mathrm{t}-1}$ & -0.010 & 0.343 & -0.029 & -0.001 & 0.020 \\
\hline DFDISP $_{t}$ & FDISP $_{\mathrm{t}}-$ FDISP $_{\mathrm{t}-1}$ & -0.008 & 0.214 & -0.015 & 0.000 & 0.012 \\
\hline DISCRET $_{t}$ & Discretion ratio & 0.150 & 0.289 & 0.015 & 0.054 & 0.163 \\
\hline DDISCRET $_{t}$ & DISCRET $_{\mathrm{t}}$-DISCRET $\mathrm{t}_{\mathrm{t}-1}$ & -0.007 & 0.301 & -0.026 & 0.000 & 0.021 \\
\hline $\mathrm{TMV}_{\mathrm{t}}$ & Market capitalization $(\$ \mathrm{~m})$ & 4,300 & 17,154 & 279 & 774 & 2,413 \\
\hline SIZM $_{t}$ & Size $\left(\log\right.$ of $\left.\mathrm{TMV}_{\mathrm{t}}\right)$ & 6.774 & 1.598 & 5.632 & 6.652 & 7.789 \\
\hline DSIZM $_{t}$ & SIZM $_{t}-$ SIZM $_{t-1}$ & 0.152 & 0.462 & -0.102 & 0.143 & 0.395 \\
\hline BADEX $_{t}$ & Business concentration & 0.840 & 0.252 & 0.649 & 1.000 & 1.000 \\
\hline GADEX $_{\mathrm{t}}$ & Geographic concentration & 0.914 & 0.181 & 1.000 & 1.000 & 1.000 \\
\hline DBADEX $_{t}$ & $\mathrm{BADEX}_{\mathrm{t}}-\mathrm{BADEX}_{\mathrm{t}-1}$ & 0.006 & 0.123 & 0.000 & 0.000 & 0.000 \\
\hline DGADEX $_{\mathrm{t}}$ & GADEX $_{\mathrm{t}}-\mathrm{GADEX}_{\mathrm{t}-1}$ & -0.006 & 0.084 & 0.000 & 0.000 & 0.000 \\
\hline ROEIM $_{t}$ & FirstCall actual EPS scaled by price & 0.045 & 0.101 & 0.020 & 0.039 & 0.063 \\
\hline DROEIM $_{t}$ & ROEIM $_{\mathrm{t}}-$ ROEIM $_{\mathrm{t}-1}$ & 0.005 & 0.037 & -0.007 & 0.002 & 0.016 \\
\hline $\mathrm{ROMO}_{\mathrm{t}}$ & Operating income scaled by price & 0.116 & 0.082 & 0.062 & 0.099 & 0.147 \\
\hline $\mathrm{DROMO}_{\mathrm{t}}$ & $\mathrm{ROMO}_{\mathrm{t}}-\mathrm{ROMO}_{\mathrm{t}-1}$ & 0.003 & 0.066 & -0.025 & 0.000 & 0.026 \\
\hline $\mathrm{ROMN}_{\mathrm{t}}$ & Non-operating income scaled by price & 0.023 & 0.024 & 0.000 & 0.008 & 0.072 \\
\hline DROMN $_{t}$ & $\mathrm{ROMN}_{\mathrm{t}}-\mathrm{ROMN}_{\mathrm{t}-1}$ & 0.001 & 0.016 & -0.002 & 0.000 & 0.003 \\
\hline CINVEST $_{\mathrm{t}-1}$ & Beginning investments to total assets & 0.158 & 0.190 & 0.015 & 0.103 & 0.221 \\
\hline
\end{tabular}

The sample comprises of US firms at the intersection of Compustat and FirstCall Databases. The statistics are computed for the just announced earnings, from 1990 through 2004. The sample comprises 25,976 firm years, of which 19,680 are industrial and commercial firms, 4,830 are financial and 1,466 are utility firms respectively. Appendix 1 describes in detail the sources of the data and the computation of the variables. 
In Table 1, the firms have quite high analysts' following (mean and median ANAFO 6.984 and 5), because of the requirement that they should have all forecast attributes such as dispersion (which requires at least two forecasts). For this reason, the sample firms are also big on average, with market capitalization in billions of dollars for most firm years. The forecasts are optimistic (negative mean FBIAS of -0.026) but the typical firm's earnings beats the analysts' forecast (median FBIAS equals 0.006). The median value suggests that at least half the sample firm years' actual earnings beat analysts' forecast. The FDISP (forecast dispersion) has mean and median of 0.066 and 0.017 respectively, suggesting that the values are negatively skewed.

The business and geographic concentration indices have median values of 1 , suggesting that the majority of firms are focused. The discretion ratio (DISCRET) shows that on average, non-operating income is small relative to operating income (mean of 0.15), but for some firms, non-operating income could be twice the operating income (the 99 percentile of DISCRET which is not included in the table, equals 2.101 times the operating income). Accordingly, the non-operating income values scaled by lagged market values (ROMN) are less on average than the operating income scaled by market value (ROMO).

The overall firm level profit (ROEIM) scaled by price at the beginning of the year is generally positive for the majority of firm years. Like most studies that require analysts' forecast attributes, it is not practicable to ascertain the results for those firms that are not followed by analysts.

\subsection{Correlation between the Variables}

In Table 2, I report coefficients for the correlation between the forecast attributes and the other financial variables. The Pearson (Spearman) coefficients are to the lower left (upper right) of the diagonal.

Table 2. Correlations

\begin{tabular}{|c|c|c|c|c|c|c|c|c|c|c|c|}
\hline Variable & $\mathrm{ANAFO}_{\mathrm{t}}$ & FDISP $_{t}$ & FBIASt & $\mathrm{FACCU}_{\mathrm{t}}$ & CINVEST $_{\mathrm{t}-1}$ & DISCRET $_{t}$ & SIZM $_{t}$ & BADEX $_{t}$ & $\mathrm{GADEX}_{\mathrm{t}}$ & $\mathrm{ROMO}_{\mathrm{t}}$ & $\mathrm{ROMN}_{\mathrm{t}}$ \\
\hline ANAFO $_{t}$ & 1 & 0.024 & -0.027 & -0.165 & 0.111 & 0.023 & 0.725 & -0.117 & -0.060 & -0.061 & 0.016 \\
\hline p-Value & & 0.00 & 0.00 & 0.00 & 0.00 & 0.00 & 0.00 & 0.00 & 0.00 & 0.00 & 0.01 \\
\hline FDISP $_{t}$ & -0.028 & 1 & -0.020 & 0.556 & -0.030 & 0.172 & -0.088 & -0.028 & -0.032 & -0.096 & 0.148 \\
\hline $\mathrm{p}$-Value & 0.00 & & 0.00 & 0.00 & 0.00 & 0.00 & 0.00 & 0.00 & 0.00 & 0.00 & 0.00 \\
\hline FBIAS $_{t}$ & 0.035 & -0.271 & 1 & 0.138 & -0.008 & 0.045 & -0.003 & 0.037 & 0.032 & -0.040 & 0.014 \\
\hline $\mathrm{p}$-Value & 0.00 & 0.00 & & 0.00 & 0.22 & 0.00 & 0.67 & 0.00 & 0.00 & 0.00 & 0.03 \\
\hline $\mathrm{FACCU}_{\mathrm{t}}$ & -0.085 & 0.524 & -0.670 & 1 & -0.050 & 0.150 & -0.205 & 0.018 & 0.001 & -0.106 & 0.115 \\
\hline $\mathrm{p}$-Value & 0.00 & 0.00 & 0.00 & & 0.00 & 0.00 & 0.00 & 0.00 & 0.83 & 0.00 & 0.00 \\
\hline CINVEST $_{\mathrm{t}-1}$ & 0.048 & -0.020 & 0.025 & -0.022 & 1 & -0.011 & 0.178 & 0.039 & 0.070 & -0.004 & -0.048 \\
\hline $\mathrm{p}$-Value & 0.00 & 0.00 & 0.00 & 0.00 & & 0.09 & 0.00 & 0.00 & 0.00 & 0.54 & 0.00 \\
\hline DISCRET $_{t}$ & 0.005 & 0.158 & -0.020 & 0.110 & -0.037 & 1 & 0.005 & -0.069 & -0.122 & -0.394 & 0.932 \\
\hline $\mathrm{p}$-Value & 0.44 & 0.00 & 0.00 & 0.00 & 0.00 & & 0.44 & 0.00 & 0.00 & 0.00 & 0.00 \\
\hline $\mathrm{SIZM}_{\mathrm{t}}$ & 0.724 & -0.080 & 0.070 & -0.131 & 0.099 & -0.019 & 1 & -0.244 & -0.120 & -0.094 & -0.011 \\
\hline $\mathrm{p}$-Value & 0.00 & 0.00 & 0.00 & 0.00 & 0.00 & 0.00 & & 0.00 & 0.00 & 0.00 & 0.08 \\
\hline BADEX $_{t}$ & -0.088 & -0.005 & 0.020 & 0.003 & 0.062 & -0.060 & -0.244 & 1 & 0.073 & -0.101 & -0.133 \\
\hline $\mathrm{p}$-Value & 0.00 & 0.38 & 0.00 & 0.66 & 0.00 & 0.00 & 0.00 & & 0.00 & 0.00 & 0.00 \\
\hline GADEX $_{t}$ & -0.061 & -0.011 & 0.014 & -0.002 & 0.125 & -0.060 & -0.148 & 0.076 & 1 & 0.081 & -0.124 \\
\hline $\mathrm{p}$-Value & 0.00 & 0.06 & 0.03 & 0.71 & 0.00 & 0.00 & 0.00 & 0.00 & & 0.00 & 0.00 \\
\hline $\mathrm{ROMO}_{\mathrm{t}}$ & -0.068 & -0.070 & 0.012 & -0.054 & 0.012 & -0.300 & -0.110 & -0.067 & 0.066 & 1 & -0.146 \\
\hline p-Value & 0.00 & 0.00 & 0.05 & 0.00 & 0.06 & 0.00 & 0.00 & 0.00 & 0.00 & & 0.00 \\
\hline $\mathrm{ROMN}_{\mathrm{t}}$ & 0.010 & 0.044 & -0.001 & 0.016 & -0.179 & 0.650 & 0.038 & -0.174 & -0.112 & -0.188 & 1 \\
\hline $\mathrm{p}$-Value & 0.10 & 0.00 & 0.89 & 0.01 & 0.00 & 0.00 & 0.00 & 0.00 & 0.00 & 0.00 & \\
\hline $\begin{array}{l}\text { Pearson (loy } \\
\text { coefficients } \\
\text { describes in }\end{array}$ & $\begin{array}{l}\mathrm{ft} \text { diagor } \\
\text { precedi }\end{array}$ & and $\mathrm{Spc}$ & $\operatorname{an}\left(u_{1}\right.$ & $\begin{array}{l}\text { right } \\
\text { are cor } \\
\text { mputa }\end{array}$ & $\begin{array}{l}\text { nal) correla } \\
\text { d using the } \\
\text { of the varia }\end{array}$ & $\begin{array}{l}\text { The } p-V \\
76 \text { firm-y }\end{array}$ & es are & $\begin{array}{l}\text { gnifica } \\
\text { is in a }\end{array}$ & $\begin{array}{l}\text { evels fo } \\
\text { ed settin }\end{array}$ & $\begin{array}{l}\text { correl } \\
\text { ppendi }\end{array}$ & \\
\hline
\end{tabular}

From the table, ROMO and ROMN (also DISCRET) are negatively correlated. This suggests that the outcome of non-operating activities are less linked to or dependent on management's operating expertise and so management use non-operating income to smooth operating income. Also, DISCRET, and FACCU and FDISP (FBIAS) are positively (negatively) correlated, suggesting that the discretion ratio is positively associated with inaccurate and diverging forecasts. However, these forecast attributes and the discretion ratio are also respectively correlated 
with the business (BADEX) and geographic (GADEX) concentration indices, the levels of operating and non-operating profitability (ROMO and ROMN), size and analyst following. Therefore, a conclusive finding on the relation between the discretion ratio and the forecast attributes requires controlling for those other variables.

\section{Findings}

To ascertain the relation between the discretion ratio and the forecast attributes, I estimate regressions of each forecast attribute on the discretion ratio. I conduct this analysis for the levels and changes in the variables. The change regression analysis provides results that approximate an assessment of causal relations among the variables.

\subsection{Incremental Relation between the Levels of Discretion Ratio and Forecasts}

In Table 3, I report regression results for the levels of the variables. I use model (4) from the methods section, and report the results for MBIAS, FACCU and FDISP as dependent variables in three different panels. I estimate the regression for each year and then summarize and report the parameters from the 15 years. I also conduct the analysis for the pooled sample and find that the results are similar. I report the annual results, which is consistent with the current fashion in academic research spanning many years, because such regressions control for the effect of serial correlation among the independent variables on the parameters.

Table 3. Incremental relation between discretion ratio and forecast attributes

\begin{tabular}{|c|c|c|c|c|c|c|c|c|c|}
\hline \multirow{2}{*}{$\begin{array}{l}\text { Exogenous } \\
\text { Variables }\end{array}$} & \multicolumn{3}{|c|}{ Model 4 (1) } & \multicolumn{3}{|c|}{ Model 4 (2) } & \multicolumn{3}{|c|}{ Model 4 (3) } \\
\hline & Slope & t-Value & $\mathrm{p}$-Value & Slope & t-Value & p-Value & Slope & t-Value & p-Value \\
\hline \multicolumn{10}{|c|}{ Panel A: Forecast attribute is mean forecast error (FBIASt) } \\
\hline Intercept & -0.0187 & -5.38 & 0.00 & -0.2771 & -6.95 & 0.00 & -0.2658 & -7.26 & 0.00 \\
\hline DISCRET $_{t}$ & -0.0649 & -3.14 & 0.01 & - & - & - & -0.0362 & -2.07 & 0.06 \\
\hline FOLLO $_{\mathrm{t}}$ & - & - & - & -0.0242 & -2.71 & 0.02 & -0.0210 & -2.53 & 0.02 \\
\hline ROEIM $_{t}$ & - & - & - & 1.4064 & 9.10 & 0.00 & 1.3647 & 9.43 & 0.00 \\
\hline SIZM $_{t-1}$ & - & - & - & 0.0273 & 5.39 & 0.00 & 0.0256 & 5.46 & 0.00 \\
\hline BADEX $_{\mathrm{t}-1}$ & - & - & - & 0.0585 & 8.74 & 0.00 & 0.0574 & 8.24 & 0.00 \\
\hline $\mathrm{GADEX}_{\mathrm{t}-1}$ & - & - & - & -0.0023 & -0.16 & 0.88 & 0.0002 & 0.02 & 0.99 \\
\hline AdjRsq & 0.0091 & & & 0.0449 & & & 0.0496 & & \\
\hline \multicolumn{10}{|c|}{ Panel B: Forecast attribute is forecast (in)accuracy $\left(F_{A C C U_{t}}\right)$} \\
\hline Intercept & 0.0832 & 17.43 & 0.00 & 0.4726 & 14.42 & 0.00 & 0.4315 & 16.20 & 0.00 \\
\hline DISCRET $_{t}$ & 0.1873 & 10.67 & 0.00 & - & - & - & 0.1458 & 8.80 & 0.00 \\
\hline FOLLO $_{\mathrm{t}}$ & - & - & - & 0.0183 & 1.78 & 0.10 & 0.0116 & 1.43 & 0.18 \\
\hline ROEIM $_{t}$ & - & - & - & -1.9637 & -15.33 & 0.00 & -1.7949 & -15.65 & 0.00 \\
\hline $\mathrm{SIZM}_{\mathrm{t}-1}$ & - & - & - & -0.0353 & -6.41 & 0.00 & -0.0313 & -6.90 & 0.00 \\
\hline $\mathrm{BADEX}_{\mathrm{t}-1}$ & - & - & - & -0.0604 & -7.88 & 0.00 & -0.0674 & -7.36 & 0.00 \\
\hline $\mathrm{GADEX}_{\mathrm{t}-1}$ & - & - & - & -0.0172 & -1.37 & 0.19 & -0.0172 & -1.92 & 0.08 \\
\hline AdjRsq & 0.0353 & & & 0.0737 & & & 0.0948 & & \\
\hline \multicolumn{10}{|c|}{ Panel C: Forecast attribute is forecast dispersion $\left(\right.$ FDISP $\left._{\mathfrak{t}}\right)$} \\
\hline Intercept & 0.0489 & 15.74 & 0.00 & 0.2568 & 8.78 & 0.00 & 0.2170 & 8.48 & 0.00 \\
\hline DISCRET $_{t}$ & 0.1606 & 6.03 & 0.00 & - & - & - & 0.1351 & 5.12 & 0.00 \\
\hline FOLLO $_{\mathrm{t}}$ & - & - & - & 0.0379 & 3.36 & 0.00 & 0.0321 & 3.35 & 0.00 \\
\hline ROEIM $_{t}$ & - & - & - & -1.3017 & -12.80 & 0.00 & -1.1545 & -14.32 & 0.00 \\
\hline $\mathrm{SIZM}_{\mathrm{t}-1}$ & - & - & - & -0.0221 & -4.21 & 0.00 & -0.0190 & -4.76 & 0.00 \\
\hline BADEX $_{\mathrm{t}-1}$ & - & - & - & -0.0358 & -4.57 & 0.00 & -0.0462 & -5.64 & 0.00 \\
\hline $\mathrm{GADEX}_{\mathrm{t}-1}$ & - & - & - & -0.0033 & -0.55 & 0.59 & 0.0038 & 0.52 & 0.61 \\
\hline AdjRsq & 0.0634 & & & 0.0737 & & & 0.1189 & & \\
\hline
\end{tabular}

Each year, I estimate a regression of each forecast attribute on DISCRET (absolute discretion ratio), with controls for variables identified in prior research to constitute drivers of the forecast attributes. I then summarize (compute mean of) the parameter estimates and report them with relevant test statistics in this table. All of these forecast attributes are computed in the month just before that in which the earnings for the year are announced. Only US firms ( $\mathrm{FIC}=0$ in Compustat) at the intersection of Compustat annual active and research files and the FirstCall detailed estimates files are studied. The operating income (Compustat annual data178) must be positive. A total of 25,976 observations over the fiscal years 1990 through 2004 are used. The minimum, average and maximum number of firm years over the 15 years from 1990 through 2004 are 90 (in 1990), 1732, and 2,349 (in 1997) respectively. Appendix 1 describes in detail the sources of the data and the computation of the variables. 
In each panel, I estimate three models, the first model has only the DISCRET as independent variable, the second has only the control variables and the third has both DISCRET and the control variables. For each of the three panels, the sign and significance of the slope parameters in the first two models are confirmed in the third model, with virtually no exception. This suggests that dependence amongst the independent variables, if any, is minimal.

In Panel A, the negative relation between FBIAS and DISCRET ratio suggests that analysts are optimistically biased as the magnitude of non-operating income increases relative to operating income. This is consistent with analysts assuming erroneously that the non-operating income is linked to the operating expertise of management. It could also be an attempt by analysts to curry favor from management for deals such as relating to investment banking.

As expected, ROEIM is positively related to FBIAS, suggesting that high profitability enables firms to beat forecasts. This is consistent with Brown (2001) and Hwang (1996). Analysts' following (FOLLO) is associated with optimism bias and this suggests that for my sample the higher the number of analysts following a firm, the greater the competition for management favor. Also, bigger firms tend to beat forecasts because they disclose more to help analysts, manage forecasts down to avoid political costs if they miss forecasts, and tend to perform well (Brown et al., 1987; Wiedman, 1996). This is confirmed by the positive relation between SIZM and FBIAS. Business concentration (BADEX) is positively associated with FBIAS, suggesting that focused businesses tend to beat forecasts, and conversely analysts are optimistic about diversified businesses in order to curry disclosure favor and mitigate the information asymmetry associated with the diversified businesses. This extends Thomas (2002) who does not examine bias for business diversification. The relation between FBIAS and GADEX is not significant, and so cannot be said to corroborate Duru and Reeb (2002).

In panel B, FACCU increases in DISCRET ratio, suggesting that analysts are less accurate as non-operating income increases relative to operating income. The relation between FACCU, and FOLLO is not significant. The FACCU decreases in ROEIM, SIZM, BADEX, and GADEX, confirming the results in panel A and the prior research. My results show that geographic focus (GADEX) is not consistently significantly associated with forecast inaccuracy. This result does not conclusively support Duru \& Reeb (2002).

Now consider Panel C, where the analysis has analysts' forecasts dispersion (FDISP) as the dependent variable. I find that FDISP is positively associated with DISCRET, and FOLLO. This suggests that analysts' opinions diverge more as non-operating income relative to operating income increases, and as analysts' following increases. A positive relation to FDISP suggests opinions amongst analysts diverges more, as they likely source their information from different sources and interpret the same disclosure and guidance from management differently. Therefore, higher non-operating income (relative to operating income) is positively associated with inherent uncertainty, likely due to analysts' lacking expertise in the non-operating activities, and wrongly linking non-operating activities to managerial expertise in operating activities. The higher the number of analysts', the more the differences in their opinions as they add their respective private information to the earnings forecast.

Still in Panel C, FDISP is negatively associated with ROEIM, SIZM, and BADEX, suggesting that analysts are more unanimous for firms that are more profitable, enjoy more disclosure from big firms (Brown et al., 1987), and do not suffer the information asymmetry associated with diversified businesses (contradicting Thomas, 2002). The relation between FDISP and GADEX is insignificant.

\subsection{Incremental Relation between the Changes in Discretion Ratio and Forecasts}

To be more conclusive about the relation between DISCRET and the forecast attributes, I move from an association perspective towards (but not exactly up to) a causal perspective. Using model (6) in the methods section, I estimate a regression of the first difference of each of the forecast attributes on the first difference of the discretion ratio and the control variables. Just as I did for the level regressions, I estimate and summarize the annual regressions in Table 4 below. 
Table 4. Incremental relation between changes in discretion ratio and changes in forecast attributes

\begin{tabular}{|c|c|c|c|c|c|c|c|c|c|}
\hline \multirow{2}{*}{$\begin{array}{l}\text { Exogenous } \\
\text { Variables }\end{array}$} & \multicolumn{3}{|c|}{ Model $5(1)$} & \multicolumn{3}{|c|}{ Model $5(2)$} & \multicolumn{3}{|c|}{ Model $5(3)$} \\
\hline & Slope & t-Value & p-Value & Slope & $\mathrm{t}$-Value & p-Value & Slope & t-Value & p-Value \\
\hline \multicolumn{10}{|c|}{ Panel A: Forecast attribute is change in mean forecast error (DFBIASt) } \\
\hline Intercept & -0.0152 & -1.55 & 0.15 & -0.0169 & -3.28 & 0.01 & -0.0175 & -3.38 & 0.00 \\
\hline DDISCRET $_{t}$ & -0.0610 & -2.66 & 0.02 & - & - & - & -0.0068 & -0.40 & 0.69 \\
\hline DFOLLO $_{t}$ & - & - & - & -0.0670 & -6.43 & 0.00 & -0.0665 & -6.60 & 0.00 \\
\hline DROEIM $_{t}$ & - & - & - & 2.5574 & 7.08 & 0.00 & 2.5399 & 7.13 & 0.00 \\
\hline DSIZM $_{t}$ & - & - & - & 0.0594 & 2.45 & 0.03 & 0.0584 & 2.42 & 0.03 \\
\hline DBADEX $_{t}$ & - & - & - & 0.0312 & 0.95 & 0.36 & 0.0285 & 0.90 & 0.38 \\
\hline DGADEX $_{\mathrm{t}}$ & - & - & - & 0.1608 & 1.22 & 0.24 & 0.1555 & 1.17 & 0.26 \\
\hline AdjRsq & 0.0035 & & & 0.0604 & & & 0.0610 & & \\
\hline \multicolumn{10}{|c|}{ Panel B: Forecast attribute is change in forecast (in)accuracy $\left(\right.$ DFACCU $\left._{t}\right)$} \\
\hline Intercept & -0.0008 & -0.11 & 0.92 & 0.0161 & 4.17 & 0.00 & 0.0156 & 4.12 & 0.00 \\
\hline DDISCRET $_{t}$ & 0.1319 & 10.65 & 0.00 & - & - & - & 0.0805 & 7.89 & 0.00 \\
\hline DFOLLO $_{\mathrm{t}}$ & - & - & - & 0.0090 & 0.69 & 0.50 & 0.0075 & 0.59 & 0.57 \\
\hline DROEIM $_{t}$ & - & - & - & -2.4960 & -9.79 & 0.00 & -2.3992 & -9.36 & 0.00 \\
\hline $\operatorname{DSIZM}_{\mathrm{t}}$ & - & - & - & -0.1034 & -5.43 & 0.00 & -0.0957 & -5.01 & 0.00 \\
\hline DBADEX $_{t}$ & - & - & - & -0.0840 & -1.72 & 0.11 & -0.0764 & -1.63 & 0.13 \\
\hline DGADEX $_{\mathrm{t}}$ & - & - & - & 0.0295 & 0.96 & 0.36 & 0.0384 & 1.28 & 0.22 \\
\hline AdjRsq & 0.0122 & & & 0.0743 & & & 0.0786 & & \\
\hline \multicolumn{10}{|c|}{ Panel C: Forecast attribute is change in forecast dispersion $\left(\right.$ DFDISP $\left._{t}\right)$} \\
\hline Intercept & -0.0069 & -2.53 & 0.03 & 0.0109 & 1.84 & 0.09 & 0.0093 & 1.97 & 0.07 \\
\hline DDISCRET $_{\mathrm{t}}$ & 0.1158 & 3.84 & 0.00 & - & - & - & 0.0816 & 3.49 & 0.00 \\
\hline DFOLLO $_{\mathrm{t}}$ & - & - & - & 0.0315 & 1.44 & 0.17 & 0.0265 & 1.47 & 0.16 \\
\hline DROEIM $_{t}$ & - & - & - & -1.2977 & -7.27 & 0.00 & -1.1968 & -6.35 & 0.00 \\
\hline DSIZM $_{t}$ & - & - & - & -0.0930 & -3.20 & 0.01 & -0.0828 & -3.39 & 0.00 \\
\hline DBADEX $_{t}$ & - & - & - & -0.0741 & -1.26 & 0.23 & -0.0610 & -1.22 & 0.24 \\
\hline DGADEX $_{\mathrm{t}}$ & - & - & - & -0.0142 & -0.36 & 0.72 & 0.0131 & 0.24 & 0.82 \\
\hline AdjRsq & 0.0264 & & & 0.0650 & & & 0.0789 & & \\
\hline
\end{tabular}

Each year, I estimate a regression of the change in each forecast attribute on DDISCRET (change in absolute discretion ratio), with controls for variables identified in prior research to constitute drivers of the forecast attributes. I then summarize (compute mean of) the parameter estimates and report them with relevant test statistics in this table. All of these forecast attributes are computed in the month just before that in which the earnings for the year are announced. Only US firms ( $\mathrm{FIC}=0$ in Compustat) at the intersection of Compustat annual active and research files and the FirstCall detailed estimates files are studied. The operating income (Compustat annual data178) must be positive. A total of 25,976 observations over the fiscal years 1990 through 2004 are used. The minimum, average and maximum number of firm years over the sample period of 1990 through 2004 are 90 (in 1990), 1732, and 2,349 (in 1997) respectively. Appendix 1 describes in detail the sources of the data and the computation of the variables.

In Panel A of the table, the change in the discretion ratio (DDISCRET) is positively associated with changes in optimism bias (DFBIAS) but this relation is not significant after controlling for changes in the determinants identified in prior research. In panel B, DDISCRET is positively related to DFACCU. This supports the results in panel B of Table 3. Therefore, increases (decreases) in non-operating income likely cause increases (decreases) in forecast inaccuracy. The results in Panel $\mathrm{C}$ show a positive relation between changes in DISCRET and changes in forecast dispersion. This supports those of the same panel in Table 3, showing that the change in DISCRET is positively associated with information asymmetry amongst analysts.

\subsection{Sensitivity Tests}

I discuss a number of robustness tests that I used to determine the sensitivity of the results to a number of factors. These relate to the definition of the discretion ratio, the effect of forecast horizon and industry categories respectively, on the results. Tables and figures for these results are available upon request.

In my definition of the discretion ratio, I did not adjust for interest expense (data15) from the non-operating income. In an alternative definition of the ratio, I adjusted for the non-operating income. I had more firm years with negative non-operating income after subtracting the interest expense. The results in this alternative analysis were quite similar to what I have reported. (Note 11) 
Forecast attributes, especially for the year, vary as time proceeds towards the earnings announcement date (see also Das, Levine \& Sivaramakrishnan, 1998). This is because interim results provide partial realizations for the year. Also, earnings news from other sources such as the industry, become available as the year progresses. My reported results control in part for the effects of the forecast horizon since I compute the forecast attributes using forecasts at the same time (the month before the earnings announcement) for all firm years.

Now, to assess the effect of the forecast horizon, I plotted the forecast attributes by quintiles of DISCRET using forecasts for the year as of each of the 12 months preceding the earnings announcement. I repeated this robustness analysis, using the fiscal year end rather than the earnings announcement month as the reference point in time. For each forecast attribute, the results of these analyses were not only similar to but strongly corroborated those based on the forecasts as of the month before earnings announcement.

Often, certain disclosure requirements have different information quality implications for industry categories. Bowen (1981) for example shows that income components could possess different qualities for the electric utility industry. Replicating the analysis for each industry group would be onerous and unnecessarily long. Therefore I repeated the analysis for each of three industry categories (industrial commercial, utilities, and financial services firms). The results for each industry category were similar, with slight variations that have no consequence on the inferences.

\section{Summary and Conclusion}

This study has examined the association between discretion in operations (the extent to which firms mix up primary and secondary sources of income) and forecast bias, inaccuracy, and dispersion. The results show that the magnitude of Discretion ratio (defined as non-operating income divided by operating income) is positively associated with forecast optimism bias, inaccuracy and forecast dispersion. The following account for the results: the non-operating activities are not operated by the investing managers and as analysts' incorporate managers' expertise to predict earnings, they make more errors due to the weak link between the earnings and the managers expertise; and, the non-operating activities add to the dimensions that analysts have to gather expertise in order to successfully' predict firms' earnings. For these reasons, analysts also rely on the private information which leads to more diverging forecasts for firms that earn significantly more non-operating income relative to operating income.

This study has contributed to the determinants of forecast accuracy and dispersion. The results are robust to controlling for variables identified in prior research to constitute determinants of forecast accuracy and dispersion. It also draws attention to the incompleteness of the measures of diversification used in the literature. By 'diversifying' into non-operating activities, managers are trying to conceal their inefficiencies in their primary operations. However, this has the effect of more optimism and diverging opinions among analysts. The forecasts are less accurate for firms that have relatively significant non-operating income. These properties of the non-operating income explain the inability of analysts to detect the Enron failure at the beginning of the decade. Most of the mischief was implemented by Enron's executives through investments and partnerships that did not require consolidation, leading to the eventual collapse of the firm. Future research can examine the implications of the relations between the non-operating income and the forecast attributes for valuation.

\section{Acknowledgements}

I appreciate very helpful comments from seminar participants at the 2004 AAFA conference, the 2005 North East Region AAA Conference and Pace University. My special thanks also go to Elaine Henry and Erin Moore, the discussants at the 2005 North East Region AAA Conference, Feng Chen of University of Toronto, and, faculty members at the University of Texas - Pan American, for their invaluable comments at a 2008 departmental seminar. All errors and mistakes remain my sole responsibility.

\section{References}

Ackman, D. (2002). Enron analysts: We was duped, Available from http://www.forbes.com.

Bowen, R. M. (1981). Valuation of earnings components in the electric utility industry. The Accounting Review, LVI(1), 1-22.

Brown, L. D., Richardson, G., \& Schwager, S. J. (1987). An information interpretation of financial analyst superiority in forecasting earnings. Journal of Accounting Research, 25(1), 49-67. http://dx.doi.org/10.2307/2491258

Brown, L. D. (2001). A temporal analysis of earnings surprises: profits versus losses, Journal of Accounting Research, 30(2), 221-241. http://dx.doi.org/10.1111/1475-679X.00010 
Das, S., Levine, C. B., \& Sivaramakrishnan, K. (1998). Earnings predictability and bias in analysts' earnings forecasts. The Accounting Review, 73(2), 277-294.

Diether K. B., Malloy, C. J., \& Scherbina, A. (2002). Differences of opinion and the cross section of stock returns. Journal of Finance, LVII(5), 2113-2141. http://dx.doi.org/10.1111/0022-1082.00490

Duru, A., \& Reeb, D. M. (2002). International diversification and analysts' forecast accuracy and bias. The Accounting Review, 77(2), 415-433.

Fairfield, P. M., Sweeney, R. J., \& Yohn. T. L. (1996). Accounting classifications and the predictive content of earnings. The Accounting Review, 71(3), 337-355.

Gebhardt, W. R., Lee, C. M. C., \& Swaminathan, B. (2001). Toward an implied cost of capital. Journal of Accounting Research, 39(1), 135-176. http://dx.doi.org/10.1111/1475-679X.00007

Hwang L., Jan, C., \& Basu, S. (1996). Loss firms and analysts' earnings forecast errors. Journal of Financial Statement Analysis, 18-30.

Liu, J., Nissim, D., \& Thomas, J. (2002). Equity valuation using multiples. Journal of Accounting Research, 40, 135-172. http://dx.doi.org/10.1111/1475-679X.00042

Lys, T., \& Soo, L. G. (1995). Analysts' forecast precision as a response to competition, Journal of Accounting, Auditing and Finance, 10(4), 751-765.

Miller, E. M. (1977). Risk, Uncertainty, and Divergence of Opinion. The Journal of Finance, 32(4), 1151-1167. http://dx.doi.org/10.1111/j.1540-6261.1977.tb03317.x

Miller, E. M. (2001). Why the low returns of beta and other forms of risk. The Journal of Portfolio Management, 40-54. http://dx.doi.org/10.3905/jpm.2001.319791

Philbrick, D. R., \& Ricks, W. E. (1991). Using Value Line and I/B/E/S analysts' forecasts in accounting research. Journal of Accounting Research, 29, 397-417. http://dx.doi.org/10.2307/2491057

Thomas, S. (2002). Firm diversification and asymmetric information: evidence from analysts' forecasts and earnings announcements. Journal of Financial Economics, 74, 373-396. http://dx.doi.org/10.1016/S0304-405X(02)00129-0

Wiedman, C. I. (1996). The relevance of the characteristics of the information environment in the selection of a proxy for the market's expectations for earnings: An extension of Brown, Richardson, and Schwager [1987]. Journal of Accounting Research, 34(2), 313-324. http://dx.doi.org/10.2307/2491505

\section{Notes}

Note 1. Howard Schilit argued that for periods leading to the scandal, analysts ignored red flags in Enron's financial reports such as one billion dollars in related party revenues and two-thirds of company profits in one quarter coming from unconsolidated affiliates (Ackman, 2002).

Note 2. For example, Peoplesoft Inc.'s, primary operations involve the design, development, and marketing of software. In its fiscal year 2002 annual report, Peoplesoft discloses \$30.6million income from investments in debt and equity securities that had cost $\$ 1.65$ billion. This investment, though of a continuing nature is secondary to the firm's primary business. For each of the 1990 through 2004 fiscal years, a minimum of 80 percent (not tabulated in this study) of firms in Compustat annual files report non-operating income.

Note 3. "Discretion" because management chooses what mix of operating or non-operating activities.

Note 4. This study does not consider Special items, Extraordinary Items, Discontinued Operations and Effects of Accounting Changes. This is because they are one-off items that are not expected to recur and so tend not to be predicted by analysts.

Note 5. If the assets are controlled by the investor, they will be consolidated under ARB 51 or FIN 46R. Though investments could be subject to significant influence due, say, to the investor being the biggest block owner, this does not amount to control and so is not consolidated under US GAAP.

Note 6. They argue that the over pricing is associated with lower subsequent returns for two reasons. First the prices will revert towards the true value by decreasing when the information asymmetry (the cause of the overpricing) resolves. Second, since the subsequent returns are computed relative to the overpriced values, they will be lower.

Note 7. I use assets to follow Duru \& Reeb (2002). Some advantages accrue to the use of assets rather than sales to compute concentration indices. For example, use of assets avoids the problem of having to adjust for 
inter-segment sales, and it also avoids the problems of distinguishing between export sales and foreign operating revenues.

Note 8. According to Philbrick \& Ricks (1991), this measure of profit tends to include income from continuing operations (that is operating and non-operating income), that it adjusts for certain special items and income tax expense, but excludes separately reported items (discontinued operations, extraordinary items and changes in accounting principle for years before 2006).

Note 9. Since I define Discretion ratio as non-operating income divided by operating income, a negative denominator would render the ratio difficult to interpret.

Note 10. I lose a lot of firms because of lack of analysts' forecasts. The dispersion measure for example requires at least two analysts' foecasts in the month before earnings announcement.

Note 11. I report the results without adjusting for interest expense because views differ as to whether they are an operating or non-operating item. Since Compustat reports them separately, I rely on those reported numbers as is commonly done.

Appendix 1. Description of the computation of the variables

\begin{tabular}{|c|c|c|}
\hline Variable & Definition & Source of data and Computation of variable \\
\hline $\mathrm{ANAFO}_{\mathrm{t}}$ & Analyst following & $\begin{array}{l}\text { FirstCall: Number of earnings forecasts for the year } t \text { in the month before earnings } \\
\text { announcement }\end{array}$ \\
\hline FOLLO $_{\mathrm{t}}$ & Log of Analyst following & FirstCall: Natural logarithm of $\mathrm{ANAFO}_{\mathrm{t}}$ \\
\hline FDISP $_{t}$ & Forecast dispersion & $\begin{array}{l}\text { FirstCall: Standard deviation divided by the absolute of the mean of the earnings } \\
\text { forecasts for the year } t \text { in the month before earnings announcement }\end{array}$ \\
\hline FBIAS $_{\mathrm{t}}$ & Forecast error & $\begin{array}{l}\text { FirstCall: Actual less mean forecast of earnings for year } t \text { in the month before } \\
\text { earnings announcement, divided by the absolute actual earnings }\end{array}$ \\
\hline $\mathrm{FACCU}_{\mathrm{t}}$ & Forecast (in)accuracy & FirstCall: Absolute value of FBIAS $_{t}$ \\
\hline DISCRET $_{t}$ & Discretion ratio & $\begin{array}{l}\text { Compustat: Non-operating income (data61) divided by operating income (data178) } \\
\text { for year } \mathrm{t}\end{array}$ \\
\hline $\mathrm{TMV}_{\mathrm{t}}$ & Market capitalization & $\begin{array}{l}\text { Compustat: Number of shares outstanding (data25) for year } t \text { times closing price per } \\
\text { share (data199) for year } t \quad(\$ \mathrm{~m})\end{array}$ \\
\hline SIZM $_{t}$ & Size & Compustat: $\log$ of $\mathrm{TMV}_{\mathrm{t}}$ \\
\hline BADEX $_{t}$ & Business concentration & $\begin{array}{l}\text { Compustat Segment: Sum of square of assets ('at') of reported business segments } \\
\text { dividend by the square of the sum of the assets for year t. }\end{array}$ \\
\hline GADEX $_{\mathrm{t}}$ & Geographic concentration & $\begin{array}{l}\text { Compustat Segment: Sum of square of assets ('at') of reported geographic segments } \\
\text { dividend by the square of the sum of the assets for year t. }\end{array}$ \\
\hline ROEIM $_{t}$ & Net Income scaled by price & $\begin{array}{l}\text { FirstCall and Compustat: FirstCall actual EPS for year } \mathrm{t} \text { scaled by price (data199) } \\
\text { for year t-1 }\end{array}$ \\
\hline $\mathrm{ROMO}_{\mathrm{t}}$ & Operating income scaled by price & $\begin{array}{l}\text { Compustat: Operating income (data178) for year t scaled by price (TMV) for year } \\
\mathrm{t}-1\end{array}$ \\
\hline $\mathrm{ROMN}_{\mathrm{t}}$ & Non-operating income scaled by price & $\begin{array}{l}\text { Compustat: Non-operating income (data61) for year t scaled by price (TMV) for } \\
\text { year t-1 }\end{array}$ \\
\hline
\end{tabular}

